\title{
Metabolism of vitamin E in sheep*
}

\author{
By M. HIDIROGLOU, K. J. JENKINS AND J. R. LESSARD \\ Animal Research Institute \\ AND R. B. CARSON \\ Analytical Chemistry Research Service, Research Branch, Canada Department \\ of Agriculture Central Experimental Farm, Ottawa, Canada \\ (Received 24 November 1969-Accepted I6 Fune 1970)

\begin{abstract}
I. The metabolism of tritium-labelled tocopherol was investigated in thirty-six wethers and forty-two ewes fed on hay known to produce nutritional muscular dystrophy (NMD).

2. In one experiment, the effect of selenium or vitamin $E$ or both on the metabolism of tritium-labelled tocopherol was studied. No difference was found in the incorporation rate of radioactivity in tissues due to the addition of either of these components.

3. In a second experiment, significantly more radioactivity was found in the tissues of sheep dosed intramuscularly than of those dosed by stomach tube into the rumen. Excretion of radioactivity was rapid when labelled tocopherol was given into the rumen.

4. In a third experiment, the efficiency of vitamin $E$ in preventing NMD in lambs was tested. Supplementation with vitamin $\mathrm{E}$ of the diet consisting of NMD-producing hay and given to ewes was ineffective as a prophylactic treatment. Direct administration of vitamin $\mathrm{E}$ to the lambs completely prevented the occurrence of NMD. Plasma vitamin E concentrations in the treated lambs were significantly higher than in untreated lambs at weekly sampling over a 4-month period regardless of whether the lambs were born from ewes treated with the vitamin or not.
\end{abstract}

The metabolic interrelationships of selenium and vitamin $\mathrm{E}$ have received considerable attention during the last few years. Calvert, Nesheim \& Scott (1962) have suggested a synergistic effect between vitamin $\mathrm{E}$ and selenium in the prevention of muscular degeneration in the chick. Desai \& Scott (1965) reported that Se is effective in increasing the retention of radioactive tocopherol in the plasma of chicks. However, Cheeke \& Oldfield (1969) did not confirm these results in rats and suggested further investigation to determine if there are species differences in the effect of Se on vitamin $\mathrm{E}$ metabolism. Thus, the work now reported was undertaken to study the relation of Se to vitamin $\mathrm{E}$ retention in sheep.

The absorption and retention of vitamin $\mathrm{E}$ administered to sheep either by stomach tube into the rumen or by injection also appeared to merit investigation. Investigations on monogastric animals by Overman, McNeely, Todd \& Wright (1954), Gloor, Weber, Wunsch \& Wiss (1963) and Imbesi (1958) indicated that oral administration of tocopherol was more effective than the parenteral route in increasing the concentration of tocopherol in the plasma. In contrast, Caravaggi, Gibbons \& Wright (1968) reported that the plasma tocopherol concentrations in sheep were higher after intramuscular than after oral administration, and Brüggemann \& Niesar (1954) reported that there was no increase of plasma tocopherol in sheep $14 \mathrm{~d}$ after intramuscular injection of vitamin $E$.

* Contribution no. 365 Animal Research Institute: contribution no. 199 Analytical Chemistry Research Service. 


\section{EXPERIMENTAL}

\section{Analytical methods}

The tissues were homogenized in $25 \mathrm{ml}$ chloroform-methanol $(2: \mathrm{I})$ per $\mathrm{g}$ of tissue and the lipids were extracted several times with a mixture of chloroform-methanol $(2: \mathrm{x})$. After evaporation of the solvent, the lipids were dissolved in $\mathrm{Io} \mathrm{ml}$ of scintillation solution (6o mg 2,5-diphenyloxazole and I mg I,4-di-2-(5-phenyloxazolyl) benzene in toluene) and counted in a Packard liquid scintillation counter $5^{\mathrm{I}} 8$. All values were converted into disintegrations/min $(\mathrm{dpm})$ by internal standardization.

Expt I. Twenty 4-month-old wethers were given hay from an area in northern Ontario where nutritional muscular dystrophy (NMD) is common. Because the hay was low in both energy and nitrogen, $2 \%$ urea and $6 \%$ sucrose were added to each day's feed supply by spraying in a water solution over the hay. All wethers received vitamin A (I0000 i.u.) and vitamin D (1750 i.u.) at weekly intervals. The wethers were divided for experimental purposes into four groups, each of five animals, and received the NMD-producing hay either unsupplemented, or were given weekly, by stomach tube into the rumen, a dose of I $\mathrm{mg}$ sodium selenite, or I $\mathrm{g} \alpha$-tocopherol, or I mg sodium selenite plus I $g \alpha$-tocopherol. After I year on these treatments, all sheep, taken one per treatment at a time, were given by stomach tube into the rumen a dose of $4.93 \times 10^{7} \mathrm{dpm} / \mathrm{kg}$ body-weight $\left[{ }^{3} \mathrm{H}\right] \mathrm{DL}-\alpha$-tocopherol-(5-methyl-T) in aqueous ethanol solution. The radioactive tocopherol $(430 \mathrm{mCi} / \mathrm{m}-\mathrm{mole}$ ) was purchased from Radiochemical Centre, Amersham, England. Blood samples were taken from each sheep $2,4,6$, ro and $24 \mathrm{~h}$ after administration of the radioisotope. All tissue samples were frozen and stored at $-20^{\circ}$ until analysed.

Expt 2. Sixteen Shropshire wethers were fed for 9 months on a NMD-producing hay. The animals were then placed in metabolism cages a few days before dosing and allowed hay and water ad lib. The tritium-labelled $\alpha$-tocopherol, in aqueous ethanol solution, was administered once, either via stomach tube into the rumen or intramuscularly into gluteal muscle, at doses that varied between $8.88 \times 10^{8} \mathrm{dpm}$ and $2.22 \times 10^{9} \mathrm{dpm}$ from trial to trial. At each time of dosing, a pair of sheep of equal weight was dosed; one sheep intraruminally and the other intramuscularly with the same amount of radioactivity.

From the four sheep killed at $24 \mathrm{~h}$, blood was collected hourly up to $\mathrm{I} 2 \mathrm{~h}$ and then at $24 \mathrm{~h}$ after dosing. Urine and faeces, if any, were collected at the same time as blood. In the other trials, blood, faeces and urine were collected at daily intervals. The collected material was handled for counting as in the previous experiment.

Expt 3. Forty-two ewes fed on a NMD-producing hay for 3 years were used for this experiment. At 2 months of gestation, twenty-three of them (group B) were given, by stomach tube into the rumen, at weekly intervals a dose of I $g$ of DL- $\alpha$-tocopherol; the remaining nineteen ewes (group A) were given no treatment. Four ewes in group B and five in group A produced twin lambs. From birth to weaning, eleven lambs from each of groups B and A were treated each week orally with $500 \mathrm{mg}$ of DL- $\alpha$-tocopherol, while the remaining sixteen of group $B$ and thirteen from group $A$ were untreated. 
Serum vitamin $\mathrm{E}$ concentrations were determined weekly by the method of Desai (1968) and serum aspartate aminotransferase (L-aspartate: 2-oxoglutarate aminotransferase; $E C$ 2.6. I. I) activities were determined every 2 weeks by the method of Reitman \& Frankel (1957).

The carcasses of all lambs, whether the animals died or were killed, were examined for gross and microscopic lesions of NMD.

\section{RESULTS AND DISCUSSION}

Expt I. The results showed a wide variation in the distribution of radioactivity in the tissues, even between animals on the same treatment. Since the standard deviation was largely proportional to the mean, it was necessary to use the logarithms of the values for the analysis of variance. After transformation, the standard deviations were more nearly equal and uncorrelated with the means. The level of statistical significance selected was $P=0.05$.

Table I. Expt I. Radioactivity of the tissues of the wethers $26 \mathrm{~h}$ after administration of a single oral dose of $\left[{ }^{3} H\right] D L-\alpha$-tocopherol

(In all experimental treatments, NMD-producing hay was given to four groups of five animals (weights $52-63 \mathrm{~kg}$ ) for I year and was either unsupplemented (control), or supplemented weekly with an oral dose of selenium, or DL- $\alpha$-tocopherol, or Se +DL- $\alpha$-tocopherol. The amount of radioactivity given to each sheep was $4.93 \times 10^{7} \mathrm{dpm} / \mathrm{kg}$ body-weight. Values are mean logarithms of $\mathrm{dpm} / \mathrm{g}$ fresh tissue with standard errors)

\begin{tabular}{lccccc}
\multicolumn{1}{c}{ Tissue } & $\begin{array}{c}\text { No } \\
\text { supplement }\end{array}$ & $\begin{array}{c}\text { Se } \\
\text { supplement }\end{array}$ & $\begin{array}{c}\text { DL- } \alpha \text {-Toco- } \\
\text { pherol } \\
\text { supplement }\end{array}$ & $\begin{array}{c}\text { DL- } \alpha-\text { Toco- } \\
\text { pherol +Se } \\
\text { supplement }\end{array}$ & SE \\
Liver & 3.8270 & 3.6226 & 3.8267 & 3.9523 & 0.2162 \\
Spleen & 3.5996 & 3.5037 & 3.7173 & 3.3316 & 0.2249 \\
Vena cava & 3.2878 & 3.0794 & 3.3147 & 3.2690 & 0.1282 \\
Abomasum & 3.5446 & 3.6107 & 3.4917 & 3.5037 & 0.3765 \\
Duodenum & 3.2723 & 3.1046 & 3.3537 & 3.3712 & 0.2960 \\
Adrenal & 3.9858 & 3.7368 & 4.0076 & 3.8830 & 0.2047 \\
Heart & 3.0120 & 3.1879 & 2.9467 & 3.1855 & 0.1940 \\
Lung & 3.4830 & 3.4641 & 3.4709 & 3.3952 & 0.1800 \\
Kidney & 3.1678 & 3.1397 & 3.4856 & 3.3699 & 0.1393 \\
Muscle & 2.9865 & 2.7677 & 2.5174 & 2.7719 & 0.1749
\end{tabular}

NMD, nutritional muscular dystrophy; dpm, disintegrations/min.

The presence or absence of Se or tocopherol in the diet of the sheep during the I 2 months before administration of radioactive tocopherol had no significant effect on the distribution of radioactivity in any of the tissues examined (Table r). These results are in agreement with the findings of Diplock, Bunyan, McHale \& Green (1967) and Green, Diplock, Bunyan, Muthy \& McHale (1967) that Se does not affect the metabolism of tocopherol in rat tissues.

According to Cheeke \& Oldfield (1969), plasma radioactivity after administration of tritiated vitamin $\mathrm{E}$ was lower in rats given a Se supplement than in untreated animals. Scott \& Thompson (I968) found that Se increased the absorption and raised blood concentrations of vitamin $E$ in chicks. On the other hand, Mukhtar (1966) reported that Se supplementation of diets for steers caused an increase in vitamin $E$ in blood 
Table 2. Expt I. Radioactivity of the blood of wethers after administration of a single dose of $\left[{ }^{3} \mathrm{H}\right] D L$ - $\alpha$-tocopherol

(In all experimental treatments, NMD-producing hay was given to four groups of five sheep (weights $52-63 \mathrm{~kg}$ ) for I year and was either unsupplemented (control), or supplemented weekly with an oral dose of selenium, or DL- $\alpha$-tocopherol, or Se $+\mathrm{DL}-\alpha$-tocopherol. The amount of radioactivity given to each sheep was $4.93 \times 10^{7} \mathrm{dpm} / \mathrm{kg}$ body-weight. Values are mean logarithms of $\mathrm{dpm} / \mathrm{g}$ fresh blood with standard errors)

\begin{tabular}{|c|c|c|c|c|c|}
\hline $\begin{array}{l}\text { Sample } \\
\text { time- } \\
\text { interval } \\
\text { (h) }\end{array}$ & $\begin{array}{c}\text { No } \\
\text { supplement }\end{array}$ & $\begin{array}{c}\text { Se } \\
\text { supplement }\end{array}$ & $\begin{array}{c}\text { DL- } \alpha \text {-Toco- } \\
\text { pherol } \\
\text { supplement }\end{array}$ & $\begin{array}{l}\text { DL- } \alpha \text {-Toco- } \\
\text { pherol + Se } \\
\text { supplement }\end{array}$ & $\mathrm{SE}$ \\
\hline I & $2 \cdot 4799$ & $2 \cdot 8949$ & $2 \cdot 9194$ & $2 \cdot 8387$ & 0.1 I 42 \\
\hline 2 & $2 \cdot 8870$ & 3.0129 & $3 \cdot I 120$ & $3 \cdot 1496$ & 0.1428 \\
\hline 4 & $2 \cdot 8986$ & $3 \cdot 2254$ & $3 \cdot 3348$ & $3 \cdot 1677$ & O.IIO3 \\
\hline 6 & $2 \cdot 8583$ & 3.0053 & $2 \cdot 9966$ & $3^{\cdot} \mathrm{I} 343$ & 0.1337 \\
\hline I 2 & $3 \cdot 1095$ & $3 \cdot 3022$ & $3.39 \times 7$ & $3 \cdot 2607$ & 0.0994 \\
\hline 24 & $3 \cdot 0987$ & $3 \cdot 3472$ & 3.3336 & $3 \cdot 3^{8} 47$ & 0.1096 \\
\hline
\end{tabular}

NMD, nutritional muscular dystrophy; dpm, disintegrations/min.

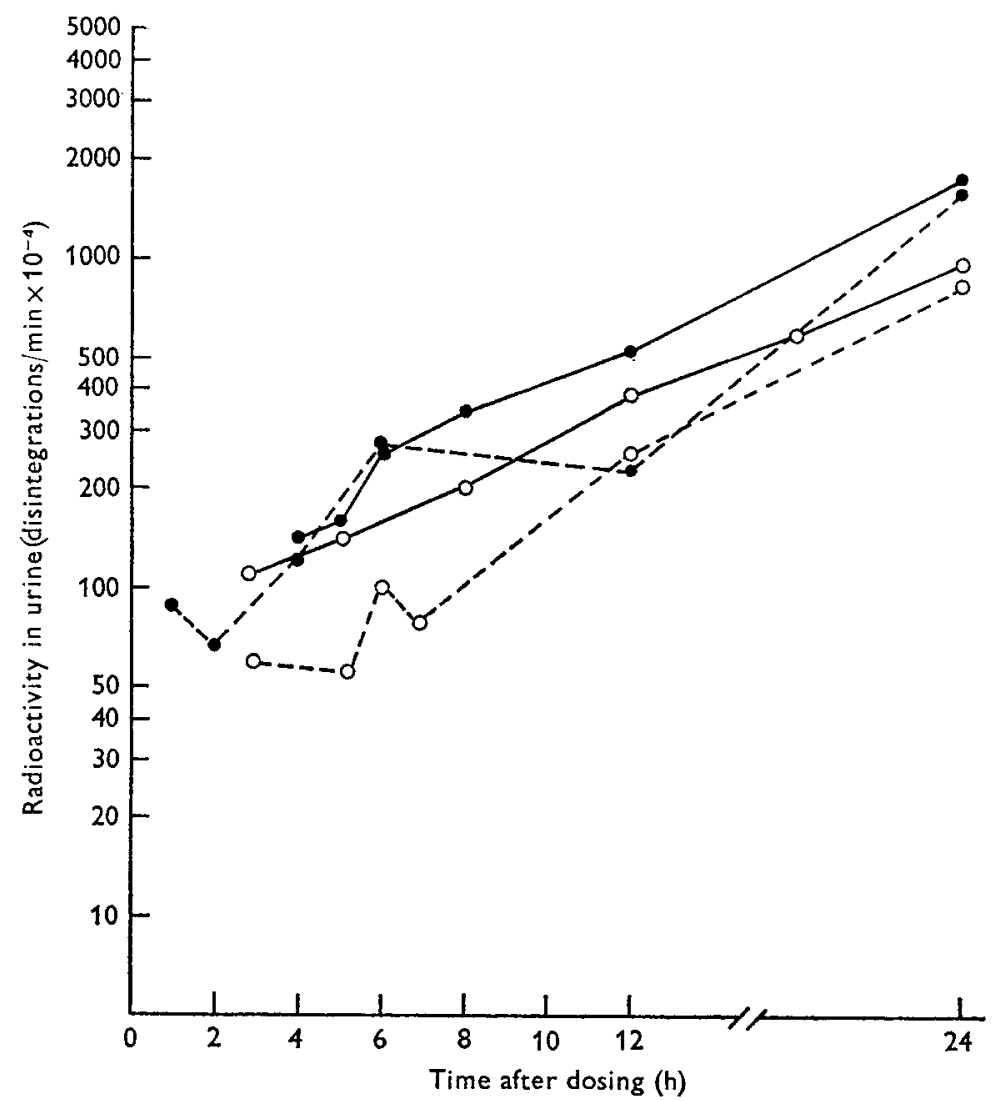

Fig. I. Urine clearance of radioactivity after administration to sheep, intramuscularly or by stomach tube into the rumen, of a single dose of $\left[{ }^{3} \mathrm{H}\right] \mathrm{DL}-\alpha$-tocopherol. - , sheep 27 $\left(8.88 \times 10^{8} \mathrm{dpm}\right.$, by stomach tube); - -, , sheep $2\left(8.88 \times 10^{8} \mathrm{dpm}\right.$, intramuscularly); O-O sheep $48\left(\mathrm{I} \cdot \mathrm{II} \times 10^{9} \mathrm{dpm}\right.$, by stomach tube); $\mathrm{O}--\mathrm{O}$, sheep $73\left(\mathrm{I}^{1} \mathrm{II} \times 10^{9} \mathrm{dpm}\right.$, intramuscularly). dpm, disintegrations $/ \mathrm{min}$. 
and a decrease in the liver. Mukhtar ( 1966 ) suggested that the reduction of vitamin $\mathrm{E}$ in the liver may be due to its transfer from liver to blood caused by Se functioning as a tocopherol carrier.

In our experiment, the presence or absence of Se or vitamin $\mathrm{E}$, or of both, in the diet of sheep before administration of $\left[{ }^{3} \mathrm{H}\right]$ tocopherol had no significant effect on the radioactivity recovered in blood at any of the sampling times (Table 2).

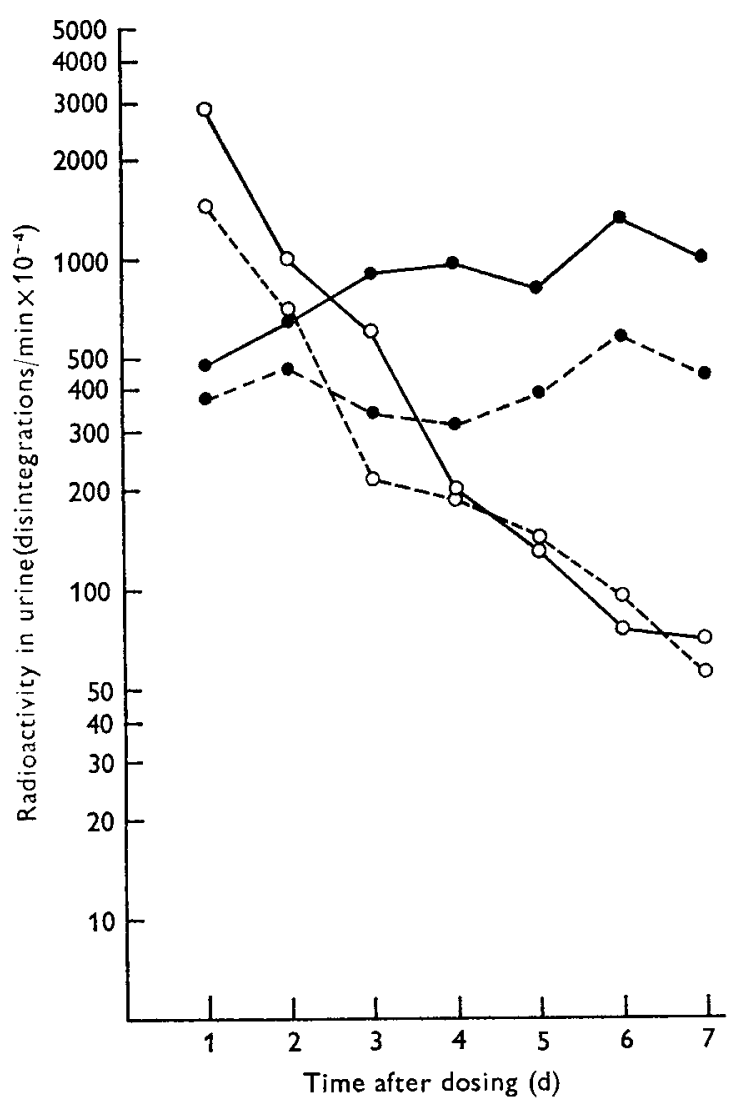

Fig. 2. Urine clearance of radioactivity after administration to sheep, intramuscularly or by stomach tube into the rumen, of a single dose of $\mathrm{I} \cdot 1 \mathrm{I} \times 10^{9} \mathrm{dpm}\left[{ }^{3} \mathrm{H}\right] \mathrm{DL}-\alpha$-tocopherol. sheep 44 (intramuscularly); - - , sheep 26 (intramuscularly); $\mathrm{O}-\mathrm{O}$, sheep 56 (by stomach tube); $\mathrm{O}_{-}-\mathrm{O}$, sheep 37 (by stomach tube). dpm, disintegrations/min.

From blood measurements taken immediately before slaughter ( $24 \mathrm{~h}$ after dosing) and from liver measurements at slaughter, regression analyses were calculated, using logarithmic transformations, to evaluate the possible relationships between these variables. The linear regression of $\mathrm{dpm}$ in blood on dpm in the liver $(r=-0.407)$ was not significant. In order to study the possibility that the relationship might be curvilinear, the analyses were again made after a second logarithmic transformation of the logarithms of dpm in the liver. The fit of the curve was not improved $(r=-0.4 \mathrm{I})$ ).

Expt 2. Maximum radioactivity in blood was recorded after 6 and $8 \mathrm{~h}$ for the intramuscular and intraruminal treatments respectively, followed by a slight decrease and 


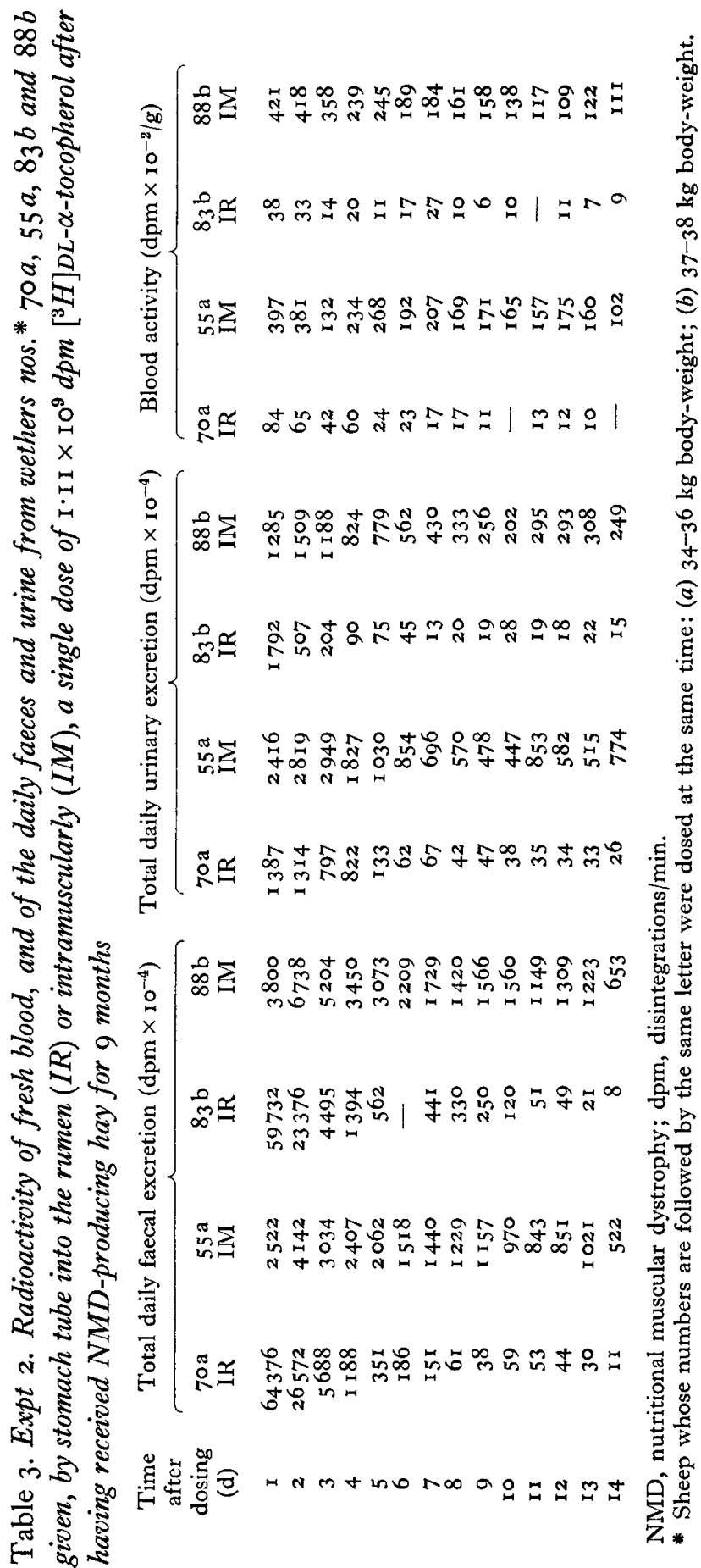


Vol. 24

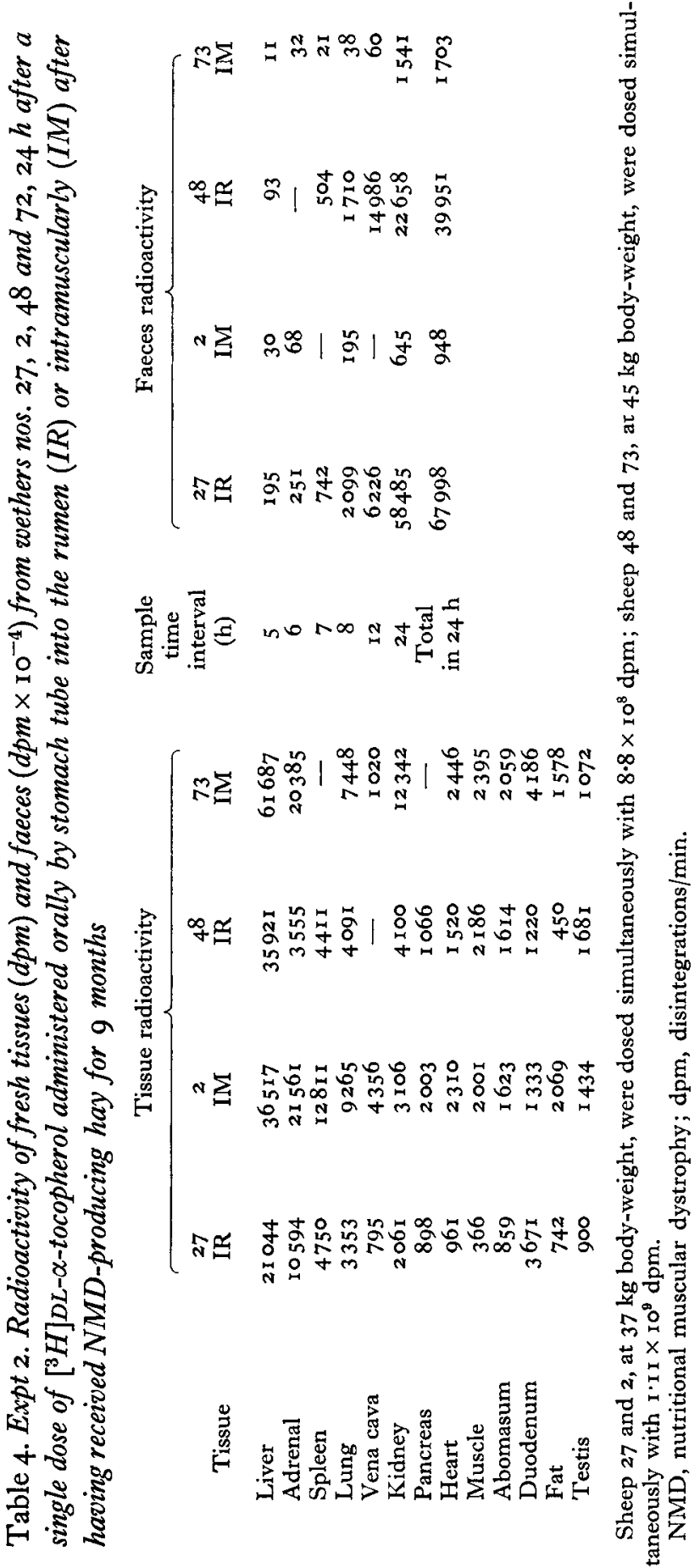


then an increase at $24 \mathrm{~h}$. At these times and thereafter, blood radioactivity concentrations were much higher in sheep dosed intramuscularly than in those dosed intraruminally.

Intraruminal and intramuscular doses of $\left[{ }^{3} \mathrm{H}\right]$ tocopherol were both rapidly excreted in the urine of sheep (Fig. I). In the sheep dosed intraruminally, the urinary radioactivity values were highest at $24 \mathrm{~h}$ and thereafter declined sharply (Fig. 2). When sheep were injected intramuscularly, urinary radioactivity increased to a maximum in $3^{-6} \mathrm{~d}$ and subsequently declined steadily (Fig. 2, Table 3 ). These results show that in the sheep dosed intramuscularly the radioactivity of both blood and urine decreased much more slowly than in those dosed intraruminally (Table 3 ). This difference could be related to the slow release of $\left[{ }^{3} \mathrm{H}\right]$ tocopherol from the site of injection into the circulatory system, if tocopherol introduced direct into the gastro-intestinal tract is eliminated rapidly. Radioactivity concentrations in the faeces indicate that sheep receiving tritium-labelled tocopherol intraruminally excreted the greater percentage of the dose during the first $3 \mathrm{~d}$; in the intramuscularly injected sheep the excretion rate was much slower (Table 3 ).

There were significant differences (at the $1 \%$ level) in the metabolism of the tritiated vitamin $\mathrm{E}$ given by either method. One or more days after treatment, retention of radioactivity in the tissues was much greater in the sheep treated intramuscularly than in those dosed intraruminally (Tables 4 and 5). There was no substantial difference in the pattern of tissue distribution due to the mode of administration.

As reported previously (Hidiroglou, Jenkins \& Carson, 1969), high uptakes of radioactivity were recorded at $24 \mathrm{~h}$ in some tissues, such as liver and adrenal, and lower uptakes in others, such as muscle (Table 5). However, at 2 weeks, these differences were less. Adipose tissue, testis and heart accumulated large amounts of radioactivity and they could be considered among the accumulator tissues. In these tissues, localization of tritiated vitamin $\mathrm{E}$ might be related to the physiological role of vitamin $\mathrm{E}$. Rindi \& Perri (1958) reported a significant increase in plasma tocopherol concentration in human beings after the parenteral administration of an aqueous solution of vitamin E. According to these authors, the ineffectiveness of intramuscular dosing reported by other investigators was due to the very slow absorption of the oil carrier which was used.

Our results are in agreement also with those of Johnson (1955) who reported that, following oral or intramuscular administration of $\left[{ }^{14} \mathrm{C}\right]$ tocopherol, the percentage of the administered radioactivity recovered in the carcasses of rats $48 \mathrm{~h}$ after dosing was higher when the dose was given intramuscularly.

Differences in the ability of individual sheep to metabolize tocopherol, as reported in Expt I, were found also in this experiment, presumably because there was variation in the rate of excretion between different sheep. The rate of excretion differed markedly with the two routes of administration of the radioactive tocopherol; vitamin $\mathrm{E}$ given orally in aqueous solution was excreted rapidly, which could explain the much lower residual radioactivity in the tissues of intraruminally treated than of intramuscularly treated sheep. 
Vol. 24

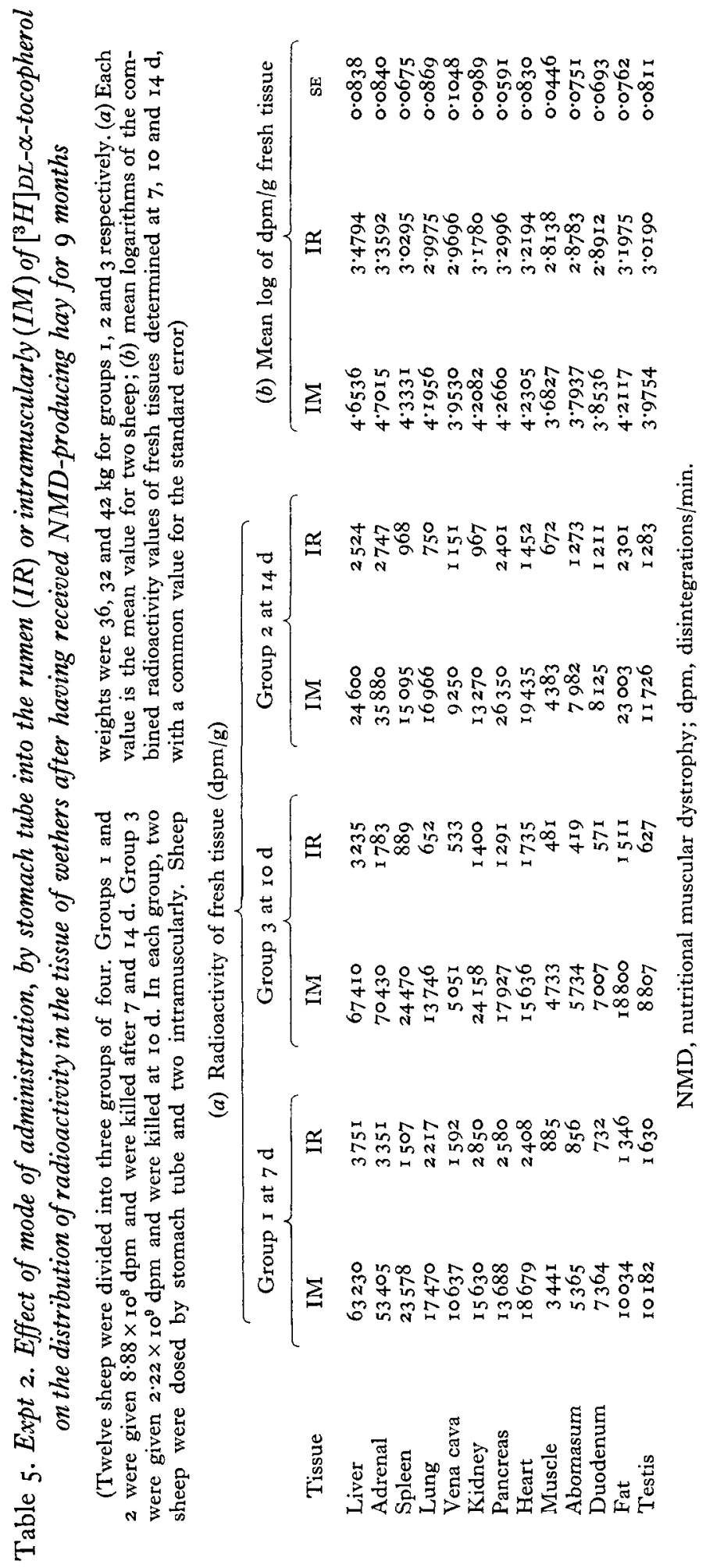







Expt 3. DL- $\alpha$-Tocopherol given direct to lambs protected them completely from death due to NMD and elevation of serum aspartate aminotransferase. No such protection, however, was obtained by the untreated lambs born from ewes given I $g$ DL- $\alpha$-tocopherol weekly, six of which died from NMD. In this experiment, no vitamin $\mathrm{E}$ determinations were made on the milk of the ewes; however, an appreciable increase of tocopherol concentrations in the milk of cows following supplementation with vitamin E has been reported by Parrish (r949) and Merk \& Crasemann (196r). On the other hand, Safford, Swingle \& McRoberts (1956) found no correlation between NMD incidence and tocopherol concentrations in ewe's milk. The fact that NMD occurs mostly in the spring, when the young grass is rich in vitamin E, suggests that the tocopherol provided by ewe's milk may be biologically unavailable to their lambs. This is supported by the present results, in which plasma vitamin $\mathrm{E}$ concentrations in the unsupplemented lambs from either treated or untreated ewes were of the same magnitude (Table 6). It is possible that either the availability to the lambs of vitamin $\mathrm{E}$ from ewe's milk was impaired by the presence of an antagonistic substance or its retention was greatly diminished by the absence of some dietary component not present in the milk.

The concentrations of vitamin $\mathrm{E}$ in the plasma were much higher in lambs dosed with vitamin $\mathrm{E}$ than in those untreated (Table 6). Although this difference was initially large, it diminished thereafter, in spite of the fact that the treated lambs continued to receive $500 \mathrm{mg}$ vitamin $\mathrm{E}$ weekly. Such decrease of plasma tocopherol concentrations with age could be related either to the diminishing capacity of a component of the plasma or to some defect in the absorption by the lambs of this lipid-soluble vitamin. The variability in the vitamin $\mathrm{E}$ concentrations of the plasma was great and was more pronounced in the vitamin E-treated lambs.

As reported previously, none of the vitamin E-treated lambs died from NMD or showed SGOT values of more than 200 Frankel Units. The percentages of untreated lambs with elevated serum aspartate aminotransferase values ( $>200$ ) at I, 3, 5, 7 and 9 weeks of age were $33,66,5^{\circ}, 45$ and 40 for the lambs born from the untreated ewes, and $15,36,37,33$ and 33 for those born from vitamin E-supplemented ewes.

According to Culik, Bacigalupo, Thorp, Luecke \& Nelson (195I), NMD in lambs is characterized by low tocopherol concentrations in blood, with critical values below $0.08 \mathrm{I} \mathrm{mg}$ of total tocopherol/100 $\mathrm{ml}$ of blood. In our experiment, death from NMD was associated with such low plasma tocopherol concentrations, and similarly low tocopherol concentrations were recorded in the plasma of untreated lambs that were healthy (Table 6) but had high serum aspartate aminotransferase values.

All the results obtained in this experiment, including those for serum tocopherol concentrations, clinical and post-mortem examinations and serum aspartate aminotransferase determinations, confirm the findings of Hogue, Proctor, Warner \& Loosli (1962) that $\alpha$-tocopherol is utilized for the prevention of NMD when given direct to the lambs but not when given to the ewes.

The authors express their appreciation to $\mathrm{Mr}$ E. Borowsky and Mr G. A. Brossard for their technical assistance. 


\section{REFERENCES}

Brüggemann, J. \&. Niesar K. H. (1954). Dt. tierärztl. Wschr. 61, 375.

Calvert, C. C., Nesheim, M. C. \& Scott, M. L. (1962). Proc. Soc. exp. Biol. Med. 1o9, 16.

Caravaggi, C., Gibbons, M. W. \& Wright, E. (I968). N.Z. Fl agric. Res. II, 3 I 3.

Cheeke, P. R. \& Oldfield, J. E. (1969). Can. F. Anim. Sci. 49, I69.

Culik, R., Bacigalupo, F. A., Thorp, F. Jr, Luecke, R. W. \& Nelson, R. H. (1951). \%. Anim. Sci. 1o, I006.

Desai, I. D. (1968). Can. Y. Physiol. Pharmac. 46, 8 I9.

Desai, I. D. \& Scott, M. L. (1965). Archs Biochem. Biophys. r 10, 309.

Diplock, A. T., Bunyan, J., McHale, D. \& Green, J. (1967), Br. F. Nutr. 21, 1 03.

Gloor, U., Weber, F., Wunsch, J. \& Wiss, O. (1963). Helv. chim. Acta 46, 2457.

Green, J., Diplock, A. T., Bunyan, J., Muthy, I. R. \& McHale, D. (1967). Br. F. Nutr. $21,497$.

Hidiroglou, M., Jenkins, K. J. \& Carson, R. B. (1969). Annls Biol. anim. Biochim. Biophys. 9, no. 2, p. $16 \mathrm{I}$.

Hogue, D. E., Proctor, J. F., Warner, R. G. \& Loosli, J. K. (I962). F. Anim. Sci. 2 r, 25.

Imbesi, A. (1958). Atti Accad. pelorit. Classe Sci. Med. Biol. 56, 373.

Johnson, B. C. (I955). Proc. int. Congr. Vitam. E. II. Venice p. 125.

Merk, W. \& Crasemann, E. (1961). Z. Tierphysiol. Tiererrähr. Futtermittelk. 16, 197.

Mukhtar, A. M. S. (1966). Some interrelationships between vitamin $\mathbf{E}$ and vitamin $A$ in the nutrition of ruminants. $\mathrm{PhD}$ Thesis, Iowa State University.

Overman, R. S., McNeely, J. M., Todd, M. E. \& Wright, I. S. (1954). F. clin. Nutr. 2, 168.

Parrish, D. B. (1949). Ann. N.Y. Acad. Sci. 52, 25 I.

Reitman, S. \& Frankel, S. (1957). Am. F. clin. Path. 28, 56.

Rindi, G. \& Perri, V. (1958). Int. Z. VitamForsch. 28, 274.

Safford, J. W., Swingle, K. F. \& McRoberts, D. E. (1956). Am. F. vet. Res. 17, 503.

Scott, M. L. \& Thompson, J. N. (1968). Selenium in Nutrition and Metabolism. In Proceedings Maryland Nutrition Conference for Feed Manufacturers, March 28-29, p. I. University of Maryland, College Park, Maryland, U.S.A. 